\title{
Developmental Phonological Error Patterns in Sentence-level Tests for Children aged 3-6 Years Old
}

\author{
Soo-Jin Kim ${ }^{\mathrm{a}}$, Young-Bin Choi ${ }^{\mathrm{a}}$, Ji-Wan $\mathrm{Ha}^{\mathrm{b}}$ \\ ${ }^{a}$ Department of Communication Disorders, Korea Nazarene University, Cheonan, Korea \\ ${ }^{b}$ Department of Speech Pathology, Daegu University, Gyeongsan, Korea
}

Correspondence: Young-Bin Choi

Department of Speech Pathology, Korea Nazarene University, 48 Wolbong-ro, Seobuk-gu, Cheonan 31172, Korea

Tel: +82-41-570-7978

Fax: +82-41-570-7846

E-mail: chldudqls8@naver.com

Received: December 15, 2020

Revised: February 1, 2021

Accepted: February 1, 2021

\begin{abstract}
Objectives: Previous studies of phonological error patterns have focused on either word or spontaneous speech levels, and have had a limited number of samples. Based on a sentence-level phonological error patterns test performed on a large sample of children, this paper compares the incidence rates of error patterns by age group and identifies age-appropriate error patterns. Methods: Speech samples of 437 children, aged between 3;0 and 6;11 years old, selected throughout Korea, were collected through the sentence-level test of the UTAP2 (Urimal Test of Articulation \& Phonology 2nd ed.). After dividing the children into 8 age groups, the incidence rates of error patterns among age groups were presented. Then, by analyzing the error patterns shown in at least $10 \%$ of the children in the same age group, age-appropriate error patterns were identified. Results: The incidence rates of phonological error patterns for fricatives, liquid, and word-medial coda were the highest. Velar fronting and tensing appeared up to age 3;5, word-final coda deletion appeared up to age $3 ; 11$, liquid deletion and stopping of fricatives appeared up to 5;5 years old, and the othersgliding, affricative stopping, deletion \& assimilation of word-medial coda appeared up to age 4;11, all of which were age-appropriate. Conclusion: The result of this study was compared with those of previous studies under different contexts (word-level and spontaneous conversational speech level). It is meaningful in that the study established a classification system of Korean developmental error patterns for speech sound disorders, and identified age-appropriate error patterns.
\end{abstract}

Keywords: Developmental phonological error patterns, Sentence-level, UTAP2, Speech sound disorders (SSD)
말소리장애 아동을 평가할 때 음운 오류패턴 분석의 목적은 많 은 말소리 오류를 보이는 아동들이 성인의 표준 발음과 다르게 발 음되는 오류 음소들 속에 어떠한 패턴이 존재하는지, 혹은 그러한 말소리 오류들 간의 관계가 어떠한지를 살펴보는 것이다(Bernthal Bankson, \& Flipsen, 2017). 음운 오류패턴 분석을 통해 치료목표 를 패턴으로 접근할 수 있도록 하고 같은 패턴의 소리 습득이 일반 화될 수 있도록 하여 치료의 효율성을 높일 수 있기 때문이다(Kim \& Shin, 2015). 또한 말소리장애 전문가들은 '원인을 모르는 말소리 장애 아동의 하위 집단을 분류하기 위해 노력하고 있다. 하위 집단 을 분류하는 일은 진단과정에서 아동의 말, 언어와 문해 발달과정 에 대한 예측과 효율적인 치료방법의 선택에 중요하기 때문이다
(Dodd, Holm, Hua, \& Crosbie, 2003; Preston, 2008). 말소리장애의 하위 집단을 분류하는 데 가장 널리 사용되는 기준의 하나는 아동 의 오류패턴으로, 전형적인 오류패턴만 있는지 혹은 비전형적인 오 류패턴도 보이는지에 따라 다른 하위 집단으로 본다. 이렇게 말소 리장애의 진단과 치료에 중요한 기준이 되는 전형적인 오류패턴을 규정하기 위해서는 대규모의 일반 아동을 대상으로 한 다양한 문 맥에서의 오류패턴 연구가 선행되어야 한다.

Dodd 등(2003)은 말소리의 음운 오류패턴이 발달적인 변동인지 아닌지를 구분해야 한다고 하면서, 전형적인 오류패턴의 구체적인 기준을 제안하였는데 자기 연령대의 $10 \%$ 이상의 아동에게서 나타 나는 것을 나이에 적절한 오류패턴으로, 자기 연령대의 $10 \%$ 이하 
아동에서 나타나지만 그 보다 어린 연령대에서는 $10 \%$ 이상 나타나 는 것을 지체된 오류패턴으로, 어떤 연령대에서도 $10 \%$ 이상 나타나 지 않는 것을 특이하고 비전형적인 오류패턴이라고 제안하면서 임 상적으로 패턴 분석의 중요성을 강조하였다. 영국 일반 아동의 전 형적 오류패턴을 살펴보면 5세 후반까지 활음화가 나타나고, 4 세 후반까지는 탈파찰음화, 3 세까지는 자음군 탈락과 전방화, 약한음 절 탈락과 파열음화가 전형적인 오류패턴으로 관찰되었다. Smit (1993)은 대부분의 공식검사가 연령 기준 5-10\%를 정상 기준으로 판정한다는 것을 근거로 한 연령에서 $5 \%$ 이상 나타나면 발달적인 것으로, $5 \%$ 미만인 경우 비발달적인 것으로 간주하였다. 국내의 오 류패턴 연구들은 이러한 기준을 우리 말소리 발달 패턴에 맞추어 조금씩 변형하여 적용하고 있다.

한국어 말소리의 습득과정에서 나타나는 전형적인 말소리 오류 패턴에 대한 연구들을 살펴보면, 대부분 단어 문맥에서의 발달적 음운 오류패턴을 분석하였다(Kim, 2006; Ha \& Kim, 2020; Hwang \& Kim, 2015; Pi \& Ha, 2020). Kim (2014)은 자발화 문맥에서 일반 아동의 전형적 음운 오류패턴을 분석하였다. 발달적으로 나타나는 전형적인 오류패턴을 연구하기 위해서 가장 중요한 연령대는 만 2 세 부터 6세까지 모국어의 음소 습득 초기부터 완성되는 시점까지를 대상으로 해야 할 것이다. 특히 2 세를 포함하려면 이상적으로는 자 발화에서 오류패턴을 연구할 필요가 있다. 그러나 자발화에서 아 동은 자신이 산출하지 못하는 음소의 산출 기회가 제한되는 등 어 려움이 있다. 또한 보다 많은 아동을 검사하고 분석하는 데 있어서 자발화 분석은 시간과 비용과 노력이 상대적으로 많이 필요한 작 업으로 참여 대상자 수에 한계가 있을 수 밖에 없다(Kim, 1992; Kim, 2006; Kim \& Lee, 2010; Kim, 2014). 시간과 비용 문제뿐 아니 라 오류 산출 기회의 효용성 측면에도 자발화는 문제가 있었다. 말 소리장애 아동을 대상으로 단어수준의 발화와 자발화를 전사하 고 오류분석 내용을 비교한 결과 대부분의 아동들이 단어수준에 서 더 많은 오류를 보였다(Kim, Kim, \& Stoel-Gammon, 2020). 자 발화에서는 말소리장애 아동이 자신이 산출하지 못하는 소리를 더 적게 산출하는 경향이 있었기 때문이다.

$\mathrm{Ha}$ 와 Kim (2020)은 650명의 아동을 대상으로 한 Urimal Test of Articulation \& Phonology 2nd ed. (UTAP2; Kim, Shin, Kim, \& $\mathrm{Ha}, 2020$ ) 단어 연구에서 상대적으로 소규모인 80 명의 아동을 대 상으로 연구한 자발화 선행연구(Kim, 2014)와 그 결과를 비교하면 서 가장 큰 차이를 보인 두 가지 변동에 대해서 논의하였다. 자발화 에서 비중 있게 다룬 경음화의 경우 평음과 격음의 경음화 모두 발 생률이 매우 낮았는데, 이러한 차이는 검사 과제의 차이로 추정하 였다. 자발화에서 말소리를 연속적으로 빠르게 연결하여 발음할
때 경음화가 발생하는 경우를 관찰할 수 있기 때문이다. 또한 다른 주요 음운변동들이 4 세에 이르면 급격하게 감소한데 반해 유음의 비음화가 5 세 후반까지 전형적인 오류패턴으로 관찰된 점에 주목 하였다. 이것은 검사 단어에 ‘로보트’와 ‘라면' 두 개의 외래어가 포 함되면서 ‘해바라기', ‘호랑이'와 같은 어중초성에서 탄설음을 산출 할 수 있는 아동들도 어두초성에서 비음으로 산출하는 경향을 보 였음을 보고하면서, 검사 항목이 오류패턴에 미치는 영향에 대한 해석에 주의가 필요하다고 하였다. 또한 $\mathrm{Pi}$ 와 $\mathrm{Ha}$ (2020)는 일반 아동 을 대상으로 Assessment of Phonology and Articulation for Children (APAC; Kim, Pae, \& Park, 2007) 단어와 개발중인 검사도구 (Korean Articulation Phonology Profile [K-APP]; Ha, Kim, Seo \& $\mathrm{Pi}$, in press) 단어에서 보인 오류패턴을 비교하였는데, APAC 오류 패턴 분석 틀을 적용하여 비교하였으며 3 회 이상 오류를 보인 경우 로 제한하였다. 같은 도구를 이용하여 새롭게 분석한 결과는 과거 의 $\operatorname{Kim}(2006)$ 의 대상자들이 보인 양상과 경음화와 음절반복에서 차이를 보인다고 하였다. 유음의 비음화와파열음화, 구개음화는 K$\mathrm{APP}$ 분석 시 2회 이상으로 분석하면 $\mathrm{APAC}$ 과 마찬가지로 발달적 패턴으로 나오지만 3회로 하면 비전형적 패턴으로 나온다고 언급 하면서, K-APP에서는 해당 오류패턴의 선정 기준을 3 회로 적용하 는 것이 다소 엄격한 기준임을 시사하는 것으로 해석하였다. 또한 음절생략과 축약은 3 세 이하 자발화에서 쉽게 관찰되는 패턴인데 $\mathrm{APAC}$ 단어 길이가 짧아서 드러나지 않았다가, 비교적 단어 길이가 긴 K-APP에서는 발달적인 패턴으로 나타났다. 음운 환경이 상이한 검사는 동일한 아동들에게 있어서도 오류패턴 출현 횟수나 관찰된 아동의 비율에서 차이가 나타난다는 것을 보여주었다. 최근의 국내 오류패턴 연구결과들은 전형적인 오류패턴의 기준을 정하는데 있 어서 관찰된 아동의 비율, 오류패턴의 출현 횟수, 검사 항목 등에 대 한 정보가 전형성의 정도를 판단하는데 함께 활용되어야 하는 것 을 보여주었다. 또한 많은 단어와 다양한 문맥을 모두 적용하여 연 구결과를 도출하는 것이 어려우므로 국내 연구결과들을 종합하여 임상에서 자발화나 문장의 평가에 활용할 수 있는 전형적인 발달 적 오류패턴 모형을 제안할 필요가 있음을 시사해 주었다.

많은 아동을 대상으로 평가하고 분석이 용이한 단어 검사 문맥 은 몇 가지 측면에서 한계점을 갖는다. 첫째, 30 개 내외의 검사 항목 을 진행하여 음소별로 단어내 위치와 음절내 위치에 따른 산출 기 회가 제한적이다. 따라서 특정 단어의 영향력이 과장될 수도 있다. '로봇, 라면'은 유음의 비음화를 빈번하고 지속적인 오류라고 판단 하도록 하며, ‘아이스크림, 파인애플'은 어중초성탈락이나 축약이 빈번한 오류패턴이라고 판단하도록 한다. 둘째, 다양한 언어학적 문맥 특히 형태소 종류나 어휘 빈도, 문장 길이와 복잡성 등에 따른 
오류 양상을 볼 수 없다. 일상에서 아동의 말언어생활에서 이러한 언어학적 문맥의 영향력은 크지만, 임상 장면에서 말소리 평가에 활용되는 단어수준 검사는 그 영향력을 축소시키는 것이다. 셋째 로 특히 연령이 높은 아동들은 반복적인 검사의 노출효과로 검사 항목과 상황에 익숙하여 일상적으로 산출하는 것보다 오류를 보이 지 않을수 있다.

이러한 문제점을 개선하기 위해서 UTAP2 (Kim, Shin et al, 2020) 는 문장 따라말하기 방법을 통해 발화를 수집, 분석하도록 하였다. 단어수준과 자발화 등 발화 유도 방법에 따른 차이를 알아보기 위 한 연구들이 진행되어 왔다. 두 문맥에서 전반적인 정확도와 오류 패턴이 유사하였다는 결과(Wolk \& Meisler, 1998)와 두 문맥 간 현 저한 차이가 나타났다는 결과도 있다(Morrison \& Shriberg, 1992). Park과 Kim (2014)에서 말소리장애 아동의 두 문맥에서의 수행을 비교한 결과, 말소리의 정확도 지표에서는 유사하였으나 오류패턴 은 특히 비전형적인 오류패턴에서 문맥 간 차이가 나타났다. 대부 분의 연구결과들은 그림 이름대기 과제에서 얻은 반응과 자발화에 서 얻은 반응 사이에는 정적 상관관계가 있다는 것을 지지하지만, 아동에 따라서는 두 가지 측정 방법에 따라 매우 다른 결과가 나타 나기도 한다(Park \& Kim, 2014; Kim, Kim et al., 2020). 아동의 말 소리를 다양한 문맥에 따라 살펴보는 것은 아동의 말소리를 정확 하게 평가하는 데에 필수적이지만 앞에서 살펴본 바와 같이 자발 화는 짧은 시간 안에 다양한 문맥에서 평가하고자 하는 것을 모두 유도하기 어려울 뿐 아니라 평가 진행 후 분석에서 많은 시간과 노 력이 필요하다.

전형적인 발달적 오류패턴 모형을 수립할 때, 그 기준으로 해당 연령의 $10 \%$ 이상 아동에게서 보이는 오류로 정하기 위해서는 연령 별 집단의 크기가 충분할 필요가 있다. 한 집단을 20 명 수준으로 하 면 단 2 명이 오류를 보여도 전형적인 오류 조건을 충족하기 때문이 다. 집단의 크기를 충분히 크게 하기 위해서 많은 연구들이 단어수 준에서 발화를 수집하여 분석하였지만 이는 실제 의사소통 상황 과 차이가 있다. 이에 대안적으로 본 연구에서는 문장수준에서 따 라말하기로 유도된 발화에서 보이는 오류패턴을 분석하고자 하였 다. 6 개월을 단위로 3 세부터 6 세까지의 일반 아동이 연령 집단별로 따라말하기 과제로 수행한 문장수준 발화에서 보인 오류패턴 비 율과 대상자 비율을 구하고 그 결과를 선행 연구들 중 자발화에서 보인 오류패턴과 비교하고, 또한 $\mathrm{Ha}$ 와 $\operatorname{Kim}(2020)$ 에서 같은 대상 자들이 단어수준에서 보인 오류패턴과 비교 논의할 것이다. 연령 별 차이에 대한 유의성이나 검사 문맥에 따른 차이는 이미 잘 알려 져 있으므로 본 연구에서는 차이검정을 실시하지 않고, 연령 집단 별로 충분한 수의 아동을 대상으로 음운 오류패턴의 출현 횟수 즉
빈도와 음운 오류패턴별로 오류를 보인 아동의 수를 비교 제시하 고자 하였다. 문장수준에서 $10 \%$ 이상의 아동이 보이는 오류패턴 이 무엇인지 찾고, 오류 출현 횟수의 백분율이 평균 $5 \%$ 이상인 오 류패턴을 찾아 임상 장면에서 자발화나 문장 과제에서 아동이 보 이는 오류패턴이 발달적인 것인지 비전형적인 것인지 판단하는 발 달적 오류패턴 모형을 제안하는 것을 목적으로 하였다.

\section{연구방법}

\section{연구대상}

본 연구의 대상은 우리말 조음음운검사2(UTAP2; Kim, Shin et al., 2020)의 규준 작업에 참여한 아동들과 동일하다. 서울경기, 충청 도, 경상도, 전라도를 중심으로 네 지역에서 어린이집, 유아원, 유치 원을 중심으로 대상자를 모집하였다. 사전 검사로 수용·표현어휘력 검사(Receptive \& Expressive Vocabulary Test [REVT]; Kim, Hong, Kim, Jang, \& Lee, 2009)와 UTAP2를 실시하여, 수용어휘력검사와 $\mathrm{UTAP} 2$ 단어수준 검사 중 한 개의 검사라도 $-2 \mathrm{SD}$ 미만인 경우는 제외하였다. 문장 검사를 수행한 3세부터 6세까지 6개월 간격으로 8 개 집단의 총 437 명이 참여하였다. 연구대상자의 특성은 Table 1 과 같다. 연령 집단별로 50 명 이상을 확보하기 위하여 노력하였으나, 3 세 전반 아동은 따라말하기 문장 검사를 실시하지 못한 경우가 많 았으며, 6세 후반은 대부분 천정점수에 도달하여 오류패턴이 나타 나지 않아서 대상자 수를 절반인 25명을 목표로 수집하였다.

\section{도구 및 절차}

아동이 거주하고 있는 집 혹은 교육기관에서 평가자와 일대일 상황으로 평가를 진행하였다. UTAP2 문장수준 검사 책자의 검사

Table 1. Demographic characteristics of study subjects

\begin{tabular}{lccc}
\hline Age $(\mathrm{yr} ; \mathrm{mo})$ & $\mathrm{N}$ & $\mathrm{PCC}(\%)$ & \multicolumn{1}{c}{ REVT-R } \\
\hline $3 ; 0-3 ; 5$ & 38 & $77.01(14.34)$ & $28.00(10.65)$ \\
$3 ; 6-3 ; 11$ & 48 & $89.96(8.68)$ & $33.35(11.61)$ \\
$4 ; 0-4 ; 5$ & 76 & $90.30(7.90)$ & $42.47(13.78)$ \\
$4 ; 6-4 ; 11$ & 67 & $92.25(7.75)$ & $49.83(10.67)$ \\
$5 ; 0-5 ; 5$ & 56 & $95.58(6.20)$ & $57.19(12.16)$ \\
$5 ; 6-5 ; 11$ & 69 & $98.43(2.24)$ & $64.68(9.69)$ \\
$6 ; 0-6 ; 5$ & 59 & $98.56(2.33)$ & $68.79(9.80)$ \\
$6 ; 6-6 ; 11$ & 24 & $99.29(0.86)$ & $78.25(11.42)$ \\
Total & 437 & $92.67(7.35)$ & $52.82(17.62)$ \\
\hline
\end{tabular}

Values are presented as mean (SD).

REVT-R=Receptive \& Expressive Vocabulary Test -Receptive vocabulary (Kim, Hong, Kim, Jang, \& Lee, 2009); UTAP2 = Urimal Test of Articulation and Phonology 2 (Kim, Shin, Kim, \& Ha 2020); PCC= percentage of correct consonants. 
문장에 해당하는 그림 단서를 보여주면서 따라말하기로 Appen$\operatorname{dix} 1$ 에 있는 11 개의 문장 발화를 유도하였다. 11 개의 문장은 47 어 절의 151 음절로 모든 자음이 3 개 이상의 다른 모음과 결합하도록 고안하였고, 각 문장은 평균 네 개의 음운 단어로 구성하였다. 3세 아동은 모두 한 문장을 두 번에 나누어 따라 말하도록 자극을 제시 하였다. 문장을 나누는 지점을 표시하여 모두에게 동일한 자극을 제공하였다. 4 세부터 6 세까지의 아동은 한 문장씩 제시하고 따라 말하도록 하였다. 아동이 전체 문장을 한 번에 따라말하기를 어려 워하는 경우에는 3 세에게 제시한 것과 같이 절반으로 자른 문장을 제시하고 따라말하도록 하였다. 전체 문장을 따라말하지 못하면 한 번 더 들려주었고, 또 실패하면 반으로 자른 문장을 제시했다. 반 으로 나눈 문장을 2회 이상 유도해도 따라말하지 못한 경우에는 연구대상에서 제외하였다. 문장 발화에서 단어를 통째로 바꾸거나 빼고 말하는 오류는 오류패턴 출현율 계산에서 분모의 기회 수를 바꾸어 자발화처럼 채점하였으며(예: 장판지를/돗자리를), 이런 오 류가 4 회 이상이면 대상에서 제외하였다. 문법형태소를 축약하는 형태의 발음(예: 돗자릴/돗자리를)은 정반응으로 처리하였다. 아동 의 모든 발화를 녹음하였으며 전사하고 음운 오류패턴 분석을 실 시하였다.

\section{자료분석}

발달적 오류패턴 기준 및 발생률 계산

오류패턴의 분류와 정의는 기본적으로 $\mathrm{Ha}$ 와 $\mathrm{Kim}$ (2020)의 발 달적 오류패턴 기준과 동일하다. 전체단어변동(음절구조변동, 동화 변동), 음운대치변동(조음방법, 조음위치, 발성유형변동)으로 범주 화 하였다. 발달적 오류패턴의 전체 분류 체계와 정의 및 출현 기회 는 Appendix 2에 제시하였다.

말소리 자동분석 프로그램인 Korean Speech Sound Analysis Tool (KSAT; Kim, Jang, Hwang, \& Chang, 2016)을 사용하여 오류 패턴 분석을 실시하였다. 문장수준 검사 전체에서 나타날 수 있는
해당 오류패턴의 기회 수에 대해 아동이 해당 오류패턴을 보인 비 율을 백분율로 계산하고 $5 \%$ 이상의 출현율을 보이는 오류유형을 살펴보았다.

Dodd 등(2003)의 기준을 따라, 각 연령 집단에서 특정 오류패턴 을 최소 2 회 이상 보인 아동이 전체 대상자 중 $10 \%$ 이상 존재할 때, 이를 그 연령대의 정상 발달 오류패턴으로 분석하였다. 더불어 $\mathrm{Ha}$ 와 $\operatorname{Kim}(2020)$ 과 같이 각 연령 집단에서 $5 \%$ 이상 $10 \%$ 미만의 아동 들이 보인 오류패턴들도 분석하였다. 동일한 오류패턴을 2 회 이상 보인 경우에만 의미 있는 오류패턴으로 간주하였다.

\section{신뢰도 및 통계분석}

전사 신뢰도를 구하기 위해 연구자 2 인이 녹음된 자료를 다시 듣 고 분석하였으며 총 51 명의 아동을 대상으로 하였다. 검사자 간 신 뢰도를 낸 결과 $94.2 \%$ 였다. 음운 오류패턴 분석의 신뢰도를 구하기 위해 연령 집단별로 전체의 $10 \%$ 에 해당하는 인원을 무작위로 선정 하여 연구자 1 인이 분석을 실시하였다. 총 45 명의 아동을 대상으로 하였다. 자동분석 프로그램과 연구자가 각각 분석한 총 2,115 어절 중 2,113 어절에 대한 오류패턴은 $99.8 \%$ 가 일치하였다.

\section{연구결과}

\section{전체단어변동}

연령 집단별 전체단어변동의 오류 평균 빈도와 표준편차 및 발 생률은 Table 2 와 같다. 모든 연령에서 오류율이 가장 높은 것은 어 중종성생략이며 다음으로 어중종성역행동화, 어말종성생략이 나 타났다. 전체단어변동 중 모든 연령에서 어중종성생략의 발생이 가 장 빈번했고 어중종성역행동화가 가장 늦게까지 나타났다. 오류 발 생률이 $5 \%$ 이상인 오류패턴과 연령을 살펴보면 어말종성생략은 3 세 전반까지, 어중종성의 생략은 4 세 전반까지, 어중종성역행동화 는 4 세 후반까지로 나타났다.

Table 2. The frequency of whole-word error patterns

\begin{tabular}{lcccccccc}
\hline Whole-word patterns & $3 ; 0-3 ; 5$ & $3 ; 6-3 ; 11$ & $4 ; 0-4 ; 5$ & $4 ; 6-4 ; 11$ & $5 ; 0-5 ; 5$ & $5 ; 6-5 ; 11$ & $6 ; 0-6 ; 5$ & $6 ; 6-6 ; 11$ \\
\hline Syllable deletion & $0.39(0.92)$ & $0.17(0.48)$ & $0.30(1.03)$ & $0.07(0.26)$ & $0.04(0.19)$ & $0.03(0.17)$ & $0.03(0.18)$ & $0.00(0.00)$ \\
& $0.4 \%$ & $0.2 \%$ & $0.3 \%$ & $0.1 \%$ & $0.0 \%$ & $0.0 \%$ & $0.0 \%$ & $0.0 \%$ \\
Word-final coda deletion & $1.24(1.57)$ & $0.60(1.03)$ & $0.50(1.11)$ & $0.33(0.81)$ & $0.18(0.43)$ & $0.10(0.30)$ & $0.10(0.30)$ & $0.09(0.28)$ \\
& $5.2 \%$ & $2.5 \%$ & $2.1 \%$ & $1.4 \%$ & $0.8 \%$ & $0.4 \%$ & $0.4 \%$ & $0.4 \%$ \\
Word-medial coda deletion & $2.68(3.13)$ & $1.10(1.70)$ & $0.99(2.10)$ & $0.46(1.00)$ & $0.45(1.01)$ & $0.14(0.35)$ & $0.10(0.36)$ & $0.13(0.34)$ \\
& $15.8 \%$ & $6.5 \%$ & $5.8 \%$ & $2.7 \%$ & $2.6 \%$ & $0.8 \%$ & $0.6 \%$ & $0.8 \%$ \\
Assimilation of word-medial coda & $0.84(1.33)$ & $0.52(0.71)$ & $0.42(0.84)$ & $0.27(0.73)$ & $0.29(0.65)$ & $0.13(0.42)$ & $0.08(0.28)$ & $0.17(0.38)$ \\
& $10.5 \%$ & $10.5 \%$ & $6.5 \%$ & $5.3 \%$ & $3.4 \%$ & $3.6 \%$ & $1.6 \%$ & $1.0 \%$ \\
\hline
\end{tabular}

Values are presented as mean (SD).

Error pattern appearance rate over $5 \%$ by age group were shaded (red color). 


\section{분절음 대치변동}

모든 연령 집단에서 가장 고빈도로 나타난 대치변동은 마찰음의 파열음화 오류였으며, 그 뒤를 이어 유음생략과 파찰음의 파열음
화, 마찰음의 파찰음화, 활음화가 고빈도로 나타나고 그 뒤를 이어 연구개음전방화와 경음화가 나타났다. 발성유형변동은 관찰되었 지만 기회의 수가 커서 발생률은 미미하였다. 연령 집단별 대치변동

Table 3. The frequency of substitution error patterns

\begin{tabular}{|c|c|c|c|c|c|c|c|c|}
\hline Substitution patterns & $3 ; 0-3 ; 5$ & $3 ; 6-3 ; 11$ & $4 ; 0-4 ; 5$ & $4 ; 6-4 ; 11$ & $5 ; 0-5 ; 5$ & $5 ; 6-5 ; 11$ & $6 ; 0-6 ; 5$ & $6 ; 6-6 ; 11$ \\
\hline Liquid deletion & $\begin{array}{c}4.50(4.31) \\
19.6 \%\end{array}$ & $\begin{array}{c}2.52(3.16) \\
11 \%\end{array}$ & $\begin{array}{c}1.82(2.87) \\
7.9 \%\end{array}$ & $\begin{array}{c}2.30(3.83) \\
10 \%\end{array}$ & $\begin{array}{c}1.21(2.79) \\
5.3 \%\end{array}$ & $\begin{array}{c}0.13(0.45) \\
0.6 \%\end{array}$ & $\begin{array}{c}0.14(0.43) \\
0.6 \%\end{array}$ & $\begin{array}{c}0.30(0.55) \\
1.3 \%\end{array}$ \\
\hline Gliding & $\begin{array}{c}1.53(2.29) \\
8.1 \%\end{array}$ & $\begin{array}{c}0.65(1.30) \\
3.4 \%\end{array}$ & $\begin{array}{c}0.62(1.57) \\
3.3 \%\end{array}$ & $\begin{array}{c}0.79(1.90) \\
4.2 \%\end{array}$ & $\begin{array}{c}0.48(1.24) \\
2.5 \%\end{array}$ & $\begin{array}{c}0.06(0.24) \\
0.3 \%\end{array}$ & $\begin{array}{c}0.02(0.13) \\
0.1 \%\end{array}$ & $\begin{array}{c}0.04(0.20) \\
0.2 \%\end{array}$ \\
\hline Nasalization (liquid errors) & $\begin{array}{c}0.50(1.25) \\
2.2 \%\end{array}$ & $\begin{array}{c}0.31(0.75) \\
1.3 \%\end{array}$ & $\begin{array}{c}0.21(0.50) \\
0.9 \%\end{array}$ & $\begin{array}{c}0.07(0.26) \\
0.3 \%\end{array}$ & $\begin{array}{c}0.07(0.32) \\
0.3 \%\end{array}$ & $\begin{array}{c}0.01(0.12) \\
0 \%\end{array}$ & $\begin{array}{c}0.03(0.18) \\
0.1 \%\end{array}$ & $\begin{array}{c}0.04(0.20) \\
0.2 \%\end{array}$ \\
\hline Stopping (liquid errors) & $\begin{array}{c}0.63(1.63) \\
2.7 \%\end{array}$ & $\begin{array}{c}0.38(1.33) \\
1.7 \%\end{array}$ & $\begin{array}{c}0.25(0.88) \\
1.1 \%\end{array}$ & $\begin{array}{c}0.07(0.44) \\
0.3 \%\end{array}$ & $\begin{array}{c}0.04(0.19) \\
0.2 \%\end{array}$ & $\begin{array}{c}0.03(0.17) \\
0.1 \%\end{array}$ & $\begin{array}{c}0.05(0.22) \\
0.2 \%\end{array}$ & $\begin{array}{c}0.04(0.20) \\
0.2 \%\end{array}$ \\
\hline Stopping (fricative errors) & $\begin{array}{c}9.92(6.98) \\
47.2 \%\end{array}$ & $\begin{array}{c}4.21(6.14) \\
20 \%\end{array}$ & $\begin{array}{c}4.57(5.63) \\
21.8 \%\end{array}$ & $\begin{array}{c}4.34(5.85) \\
20.7 \%\end{array}$ & $\begin{array}{c}1.43(3.77) \\
6.8 \%\end{array}$ & $\begin{array}{c}0.41(1.98) \\
2 \%\end{array}$ & $\begin{array}{c}0.19(0.68) \\
0.9 \%\end{array}$ & $\begin{array}{c}0.00(0.00) \\
0 \%\end{array}$ \\
\hline Affrication (fricative errors) & $\begin{array}{c}2.66(3.91) \\
12.7 \%\end{array}$ & $\begin{array}{c}1.17(2.90) \\
5.6 \%\end{array}$ & $\begin{array}{c}1.22(3.32) \\
5.8 \%\end{array}$ & $\begin{array}{c}0.91(2.36) \\
4.3 \%\end{array}$ & $\begin{array}{c}0.52(2.12) \\
2.5 \%\end{array}$ & $\begin{array}{c}0.17(1.03) \\
0.8 \%\end{array}$ & $\begin{array}{c}0.42(2.08) \\
2 \%\end{array}$ & $\begin{array}{c}0.00(0.00) \\
0 \%\end{array}$ \\
\hline Stopping (affricative errors) & $\begin{array}{c}4.74(4.43) \\
26.3 \%\end{array}$ & $\begin{array}{c}1.38(2.76) \\
7.7 \%\end{array}$ & $\begin{array}{c}1.26(2.01) \\
7 \%\end{array}$ & $\begin{array}{c}1.63(3.54) \\
9.1 \%\end{array}$ & $\begin{array}{c}0.41(1.32) \\
2.3 \%\end{array}$ & $\begin{array}{c}0.09(0.28) \\
0.5 \%\end{array}$ & $\begin{array}{c}0.15(0.61) \\
0.8 \%\end{array}$ & $\begin{array}{c}0.04(0.20) \\
0.2 \%\end{array}$ \\
\hline Velar fronting & $\begin{array}{c}1.21(2.85) \\
4.7 \%\end{array}$ & $\begin{array}{c}0.33(0.72) \\
1.3 \%\end{array}$ & $\begin{array}{c}0.46(0.93) \\
1.8 \%\end{array}$ & $\begin{array}{c}0.24(0.58) \\
0.9 \%\end{array}$ & $\begin{array}{c}0.32(1.22) \\
1.2 \%\end{array}$ & $\begin{array}{c}0.17(0.54) \\
0.7 \%\end{array}$ & $\begin{array}{c}0.00(0.00) \\
0 \%\end{array}$ & $\begin{array}{c}0.00(0.00) \\
0 \%\end{array}$ \\
\hline Tensing (aspiration) & $\begin{array}{c}0.68(1.21) \\
3.6 \%\end{array}$ & $\begin{array}{c}0.10(0.31) \\
0.5 \%\end{array}$ & $\begin{array}{c}0.24(0.60) \\
1.3 \%\end{array}$ & $\begin{array}{c}0.15(0.56) \\
0.8 \%\end{array}$ & $\begin{array}{c}0.05(0.23) \\
0.3 \%\end{array}$ & $\begin{array}{c}0.03(0.17) \\
0.2 \%\end{array}$ & $\begin{array}{c}0.10(0.36) \\
0 \%\end{array}$ & $\begin{array}{c}0.00(0.00) \\
0 \%\end{array}$ \\
\hline Tensing (lax) & $\begin{array}{c}0.63(1.57) \\
1.5 \%\end{array}$ & $\begin{array}{c}0.04(0.20) \\
0.1 \%\end{array}$ & $\begin{array}{c}0.17(0.60) \\
0.4 \%\end{array}$ & $\begin{array}{c}0.07(0.26) \\
0.2 \%\end{array}$ & $\begin{array}{c}0.05(0.30) \\
0.1 \%\end{array}$ & $\begin{array}{c}0.00(0.00) \\
0 \%\end{array}$ & $\begin{array}{c}0.02(0.13) \\
0 \%\end{array}$ & $\begin{array}{c}0.00(0.00) \\
0 \%\end{array}$ \\
\hline
\end{tabular}

Table 4. Percentage of children in each group using phonological error patterns $(\%)$

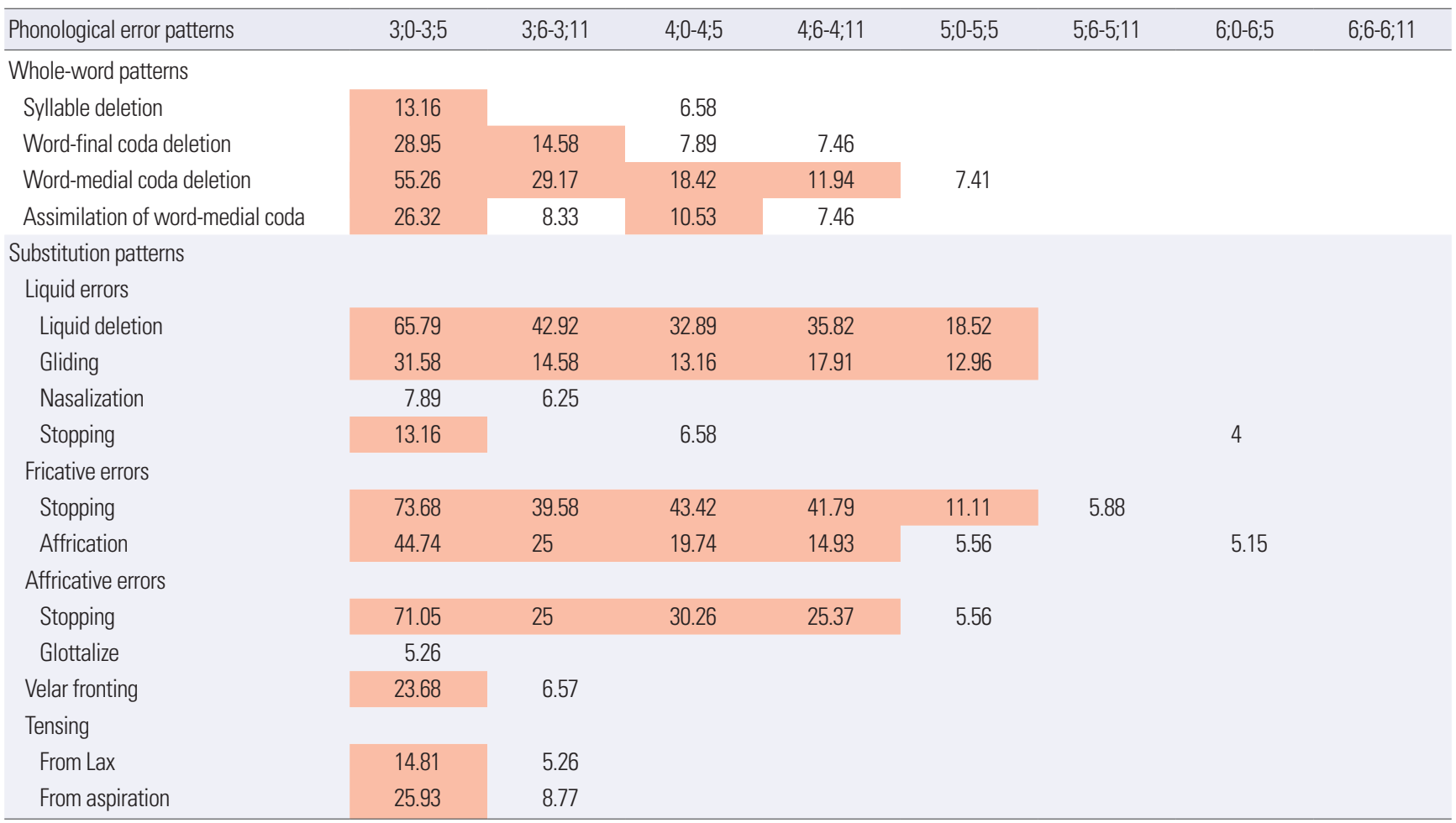

Age groups that had over 10\% of children with respective error pattern were shaded (red color). 
의 발생 빈도 및 비율은 Table 3과 같다. 이 표의 오류패턴은 모두 발생률이 5\% 이상인 오류들로 유음오류, 마찰음오류, 파찰음오류, 연구개음전방화, 경음화 순서이다.

대치변동에서 연령별로 발생률이 $5 \%$ 이상인 오류패턴을 살펴보 면 마찰음의 파열음화와 유음생략이 5세 전반까지 나타났으며, 다 음으로 파찰음의 파열음화가 4 세 후반까지, 마찰음의 파찰음화가 4 세 전반까지 나타났다. 연구개음의 전방화는 3 세 전반에도 $4.7 \%$ 였다.

\section{오류패턴을 보인 아동의 비율}

3 세부터 6세까지 6개월 단위의 연령 집단별로 $5 \%, 10 \%$ 이상의 아동이 보인 음운 오류패턴은 Table 4 와 같다. $10 \%$ 이상의 아동이 보인 칸을 검은 색으로 표시하고 5-9\%의 아동이 보인 칸은 아동 비 율만 숫자로 표시하였다. 빈칸은 오류를 보인 아동의 비율이 $5 \%$ 미 만이다. 가장 많은 아동이 오랫동안 보인 오류는 마찰음의 파열음 화와 파찰음화, 파찰음의 파열음화, 유음의 생략과 활음화 그리고 어중종성생략이었다.

\section{논의 및 결론}

말소리장애 아동 중재의 효율성을 높이고 적절한 중재 목표를 세우기 위해서 다양한 문맥에서의 음운 오류패턴 분석이 필요하 다. 기존의 국내 선행연구들은 주로 단어 문맥에서 음운 오류패턴 을 살펴보았고 제한된 수의 아동을 대상으로 발달적 오류패턴 연 구가 진행되었다. 그러나 문맥과 대상자 수의 한계로 우리말소리의 발달적 특징을 대표하기에 부족하며, 특히 특정 검사의 문항이 아 닌 일상의 발화나 문장에서 적용하는데 한계가 있었다. 그러므로 본 연구에서는 상대적으로 어려운 음소를 포함하기 어려운 자발화 를 대신하여, 따라말하기로 미리 기획한 문장을 유도하였다. 문장 수준에서 보인 오류 빈도(발생률)와 오류패턴을 보인 아동의 수(비 율) 결과를 이전의 단어수준에서 수행된 오류패턴 분석 연구결과 와 자발화 수준에서 수행된 이전 연구들과 비교하고자 하였다. 그 리고 논의에서 최종적으로는 임상 장면에서 아동이 보이는 오류패 턴이 발달적인 것인지 특이한 것인지 판단하는 데 기준이 될 수 있 는 발달적 오류패턴 모형을 제안하는 것을 목적으로 하였다. 이는 전체단어변동과 음운대치변동으로 나누어서 살펴보고자 하였다.

우선 $10 \%$ 이상의 아동이 문장수준에서 보인 전체단어변동은 음절생략과 어말종성생략, 어중종성생략, 어중종성역행동화 네 가 지 오류패턴이다. 2 세 자발화에서 관찰되었던 음절생략은 단어수 준에서는 나타나지 않았었다(Kim, 2014; Ha \& Kim, 2020). 문장 따라말하기 과제에서는 3 세 초반에 $13 \%$ 의 아동에게서 관찰되었
다. 2 회 이상 보인 아동의 수는 이렇게 많이 나타났으나 오류 빈도 와 발생률은 매우 미미한 수준이었다. 또한 대부분이 문법형태소 의 탈락으로 과연 조음 측면에서의 오류인지 언어 측면에서의 오류 인지 논란의 여지가 있다. 자발화 구어에서 문법형태소는 자연스럽 게 생략하고 말하므로 음절생략으로 분석하지 않겠지만, 따라말하 기라는 과제 특성에서 비롯된 것으로 해석된다.

우리 말소리 발달에서 음절생략보다 주목해야 할 전체단어변동 은 어절내 위치와 음소 특징에 따른 세 가지 종성오류이다. 종성오 류는 자발화 분석(Kim, 2014; Ha \& Hwang, 2013; Woo \& Kim, 2013)에서 어말종성생략은 3세경 사라지고 어중종성생략이나 어 중종성역행동화는 4 세경에 사라지는 것으로 알려져 있다. 본 연구 의 대상자들이 산출한 단어수준 음운 오류패턴 분석 결과에서도 어말종성생략은 3 세 후반까지만 나타났고, 어중종성생략은 4 세 후 반까지 나타났다. 대부분의 어중종성역행동화는 어중종성생략과 그 발생 원인이 유사한 것으로 해석되는데 4 세 후반까지 나타난 것 이다(Ha \& Kim, 2020). 본 연구에서도 어말종성생략은 3세 후반 에 사라지고 어중종성생략은 4 세 후반에 사라졌다. 다만 약간의 차이를 보인 것은 어중종성역행동화인데 문장수준 과제에서 4 세 전반까지 $10 \%$ 이상의 아동에게서 나타나 단어보다 조금 빠르게 사 라졌다. 그러나 불과 6 개월 차이로 큰 의미를 부여하기는 어렵다. 임 상 현장에서 말소리장애 아동의 오류를 분석할 때 어중종성생략 이 빈번하게 나타나는 아동은 어중종성역행동화도 빈번하게 나타 날 것이다. 표면적으로 나타난 말소리 오류패턴은 다르지만, 기저에 서 어중종성이 후행하는 어중초성에 영향을 받아서 유사한 자질 로 변화한다는 현상이 동일하기 때문이다.

다음으로 살펴 볼 분절음 대치변동은 크게 다섯가지 오류패턴 으로 묶을 수 있었다. 먼저 조음방법에서 마찰음오류, 유음오류, 파 찰음오류 세 가지가 있고, 조음위치의 연구개음전방화가 있고, 마 지막으로 발성유형에서 경음화가 있다. 마찰음의 파열음화, 마찰음 의 파찰음화와 유음생략, 유음의 활음화 오류는 자발화와 단어 모 든 연구에서 가장 오랫동안 가장 많은 아동에게서 관찰된 오류패 턴이었다. 문장 과제에서 발생률과 아동 수에서 모두 압도적인 오 류패턴은 마찰음의 파열음화로 5세 전반까지 나타났다. 다른 마찰 음 오류로는 마찰음의 파찰음화로 4 세 후반까지 나타났다. 단어 과 제에서는 4 세 후반까지만 $10 \%$ 이상의 아동이 마찰음 파열음화를 보였던 것과 비교할 때 문장 과제에서는 조금 더 늦은 5 세 전반까지 나타났다.

유음오류에서 가장 높은 빈도를 보인 것은 생략으로 아동 수는 마찰음의 파열음화와 유사한 수준이었으나, 오류 발생률에서는 마 찰음보다 낮은 것으로 나타났다. 유음생략 다음으로 많이 나타난 
유음오류는 유음의 활음화였다. 유음생략과 유음의 활음화는 자 발화와 단어에서 오류패턴을 분석한 선행연구들에서도 유음 오류 의 가장 대표적인 형태였다. 설측음과 탄설음으로 나누어서 유음 오류를 살펴본 자발화 연구에서 설측음은 생략이 가장 많이 나타 나고 다음으로 활음화가 나타난 반면, 탄설음은 활음화가 가장 많 이 나타나고 다음으로 생략이 많이 나타났다(Choi \& Kim, 2013). 자발화와 단어 연구에서 모두 생략과 활음화 이외에도 설측음과 탄설음 모두 비음화와 파열음화가 약간 나타났다. 특히 $\mathrm{Ha}$ 와 Kim (2020)의 단어수준 연구에서는 비음화가 지나치게 오래 많이 나타 났으며 이에 대해 ‘로봇'과 ‘라면’ 두 단어가 어두초성에서 비음화 오류를 보였기 때문이라고 해석하였다. 자발화 연구와 유사하게 문 장수준의 오류분석에서도 5 세 전반까지는 유음생략이 나타났고, 4세 후반까지 유음의 활음화가 나타났다.

파찰음 오류는 이전의 자발화 연구에서 파찰음의 파열음화가 4 세까지 $25 \%$ 이상의 아동에게서 관찰되었었다(Kim, 2014). 이 연구 의 과제를 문장 따라말하기로 바꾸었고 대상자를 세 배 이상 늘렸 음에도 4 세 후반까지 $25 \%$ 의 아동이 2 회 이상의 파찰음의 파열음 화를 보인 동일한 결과를 보였다. 이전의 자발화 연구는 4 세까지만 분석하였기에 5 세 이후 파찰음의 파열음화와 다른 음운 오류패턴 이 언제 사라지는 지 알 수 없었다. 유사한 오류산출 아동 수를 보 인 이번 연구는 만 6세까지 살펴보았기 때문에 자발화에서도 오류 패턴이 사라지는 연령을 추정할 수 있도록 해준다. 마찰음의 파열 음화는 5 세 전반까지 지속되었지만, 파찰음의 파열음화는 4 세 후 반까지만 지속되는 것으로 나타났다. 동일한 아동이 수행한 단어 수준의 오류패턴 분석에서는 문장수준과 동일하게 4 세 후반까지 $10 \%$ 이상의 아동들이 파찰음의 파열음화를 보이는 것으로 나타났 다. 비율이 높지는 않지만 최초 분석틀에는 포함되지 않았던 경구 개파찰음의 성문음화가 3 세 초반의 $5 \%$ 이상 아동들에서 나타나 결과에 포함된 것 또한 주목할 필요가 있다. 단어 문맥이나 자발화 에서는 관찰되지 않았던 현상으로 / ᄌ, 찌에서는 관찰되지 않았 고, 격음/ㅊ/가//로 대치된 형태이며, 대부분 어두 위치//창바끄 로, 친구, 춤, 참/)에서 나타났다. 이유를 정확히 알 수는 없지만, 몇 가지 추론이 가능하다. 이 현상은 /ㅊ/금소에서 파찰음의 운동적 복잡성과 어두에서 격음의 지각적 돋들림 때문이라고 여겨진다. 우 리말소리에서 파찰음은 치경 위치에서 짧은 폐쇄 후 경구개 쪽으로 서서히 개방되는 방법적 특징을 갖는다. 이는 짧은 폐쇄와 지연 개 방이라는 방법적 특징을 동시에 갖기 때문에, 이를 성공적으로 산 출하기 위해서는 조음적 민첩성이 요구된다. 어린 아동의 경우 빠 르고 역동적으로 움직이는 연속 발화에서 조음의 민첩성과 정확성 을 엄격하게 지키기는 쉽지 않을 것이다. 따라서 이에 대한 부담이
조음운동적 약화를 초래하였을 가능성, 이와 더불어 청지각적으 로 돋들렸던 어두 기식성을 산출하기 위해 쉬운 기식음 즉 성문음 으로 대치하였을 가능성을 생각해볼 수 있다. 이 연구에서 유독 성 문음화 오류패턴이 더 관찰된 다른 이유는 모방한 문장수준 과제 에 어두 격음/ㅊ/가 다수 포함되어 있기 때문으로 여겨진다. 파찰 음 산출 기회 19 회 중 9 회가 격음이고, 그 중 절반이 어두였기 때문 이다(Appendix 1). 음운대치 오류패턴을 분류하면서 전체단어변 동과 음운대치변동을 나누고 다시 조음방법, 조음위치, 발성유형 을 구분하여 분석하지만, 결국은 어절내 위치와 음절내 위치 그리 고 음운의 특성을 모두 종합적으로 볼 필요가 있음을 시사하는 현 상이라고 할 수 있겠다.

조음위치 측면에서는 연구개음이 어렵기 때문에 설정음화, 즉 치 경음이나 경구개음으로 전방화 되는 것이 모든 언어권 아동의 음 운습득과정에서 관찰된다. 분석 과정에서 연구개음전방화는 몇 가 지 수정 절차를 거쳤다. 초기 분석 모형에서는 우선 초성과 종성으 로 나누었다. 또한 설정음화 되는 것과 양순음화 되는 것 모두 전방 화라고 할 수 있으므로 설정음화와 양순음화로 나누어서 살펴보았 다. 1 차 결과 분석 과정에서 3 세전반에서도 양순음화는 거의 관찰 되지 않아서 발달적 오류패턴에서 삭제하였고, 종성 $/ 0 /, / 7 /$ 은 전 방화 판단 과정에서 전사 신뢰도가 낮아서 포함시키는 데 어려움 이 있었다. 최종 결과 정리 과정에서 종성의 연구개음전방화는 분 석 대상에서 제외하고 초성의 연구개음전방화만을 분석에 포함하 였다. 초성의 연구개음은 우리말소리에서 폐쇄음만 있다. 치경음이 나 양순음과 비교해서 상대적으로 나중에 습득되기는 하지만, 조 음방법 면에서 폐쇄음은 초기 발달 음소로 3세 이전에 잘 산출하 는 아동이 많다(Ha \& Hwang, 2013). 우리말소리에서 연구개폐쇄 음의 사용 빈도 역시 매우 높은 편이며, 따라서 외국 아동들에 비해 훨씬 빠른 연령에 습득되는 것으로 알려져 있다(Kim, Kim, \& StoelGammon, 2017; Kim \& Shin, 2020). 이렇게 연구개음이 빠르게 습 득되므로, 문장 과제에서도 단어 과제나 자발화 연구와 유사하게 연구개음전방화라는 오류패턴이 3세 전반이라는 비교적 빠른 시 기에 사라지게 하는 것으로 나타났다.

발성유형 측면에서 일어나는 주요 오류패턴은 경음화이다. 경음 화의 기원은 두 가지로 평음이 경음화되거나 격음이 경음화되는 것 이며, 오류율과 오류를 보인 아동의 수 모두 격음이 경음화되는 경 우가 더 많았다. 세 가지 발성유형의 난이도 측면에서 격음이 가장 어렵고 나중에 발달되는 것은 이미 잘 알려져 있으며 이런 발달 순 서가 오류패턴에 반영된 것이라고 할 수 있을 것이다. 자발화 연구 에서 연구개음전방화는 2 세까지 많이 관찰되었지만 4 세에는 사라 진 변동이었고(Kim, 2014). 단어 연구에서는 3세 전반까지 빈번한 
Table 5. Korean phonological error patterns used by $10 \%$ of children

\begin{tabular}{lccccccc}
\hline Phonological error patterns & $3 ; 0-$ & $3 ; 6-$ & $4 ; 0-$ & $4 ; 6-$ & $5 ; 0-$ & $5 ; 6-$ & $6 ; 0-$ \\
& $3 ; 5$ & $; 11$ & $4 ; 5$ & $; 11$ & $5 ; 5$ & $; 11$ & $6 ; 5$ \\
\hline Fricative stopping & & & & & & & \\
Fricative affrication & & & & & & & \\
Liquid deletion & & & & & & \\
Liquid gliding & & & & & & \\
Affricative stopping & & & & & \\
Word-medial coda deletion & & & & & \\
Assimilation word-medial coda \\
Word-final coda deletion
\end{tabular}

오류패턴이었다. 문장수준에서도 3 세 전반까지 $10 \%$ 이상의 아동 에게서 관찰되었다.

위에서 문장수준에서 보인 음운 오류패턴을 기존의 단어수준과 자발화에서 분석한 결과와 비교하여 보았다. 오류패턴 분석에 있 어서 같은 틀을 사용한 자발화 연구(Kim, 2014)는 다른 대상자의 소수 아동이었던 것에 비해, 단어수준 연구(Ha \& Kim, 2020)는 동 일한 아동들을 대상으로 수집한 발화 자료였음에도 불구하고 자 발화 분석 결과와 더 유사하였다. 본 연구의 문장수준에서 분석한 오류패턴을 중심으로, 기존의 자발화와 단어수준의 오류패턴 분 석 결과에서 공통적으로 관찰된 한국어 말소리 습득과정에서 사 라지는 음운 오류패턴을 연령별로 정리해본다면 Table 5와같다. 연 령별로 살펴본다면 3 세에 사라지는 변동은 연구개음전방화, 경음 화, 어말종성생략이었다. 다음으로 4 세에 사라지는 변동은 마찰음 의 파찰음화와 파찰음의 파열음화, 유음의 활음화, 어중종성생략 과 역행동화였다. 또한 5 세 전반에 사라지는 변동은 치경마찰음의 파열음화와 유음생략이었다. 5 세 전반이 되면서 발달적 음운 오류 패턴은 거의 사라진다고 할 수 있을 것이다.

Table 5는 문장수준에서 도출된 발달적 오류패턴을 이전의 단어 수준에서 관찰된 오류패턴과 자발화에서 관찰된 오류패턴과 비교 하고, 모든 문맥에서 공통적으로 나타난 오류패턴을 연령별로 정 리한 것으로 이 결과는 특정 문맥에 국한시키지 않고 다양한 문맥 에서 비교 활용될 수 있을 것으로 기대된다. 이렇게 전형적인 발달 적 음운 오류패턴을 자세하게 제시하고자 노력하는 이유는 역설적 이지만 비발달적이고 특이한 비전형적 오류를 파악하기 위한 기초 작업이라고 할 수 있다. 말소리장애 아동의 진단과정에서 비전형적 인 오류패턴을 보이는지 판단하는 것은 보다 효율적인 중재전략수 립에 필수적이라고 할 수 있다. 비전형적인 소리 변화는 발달적 소 리 변화보다 더 심각한 것으로 판단되며, 아동의 음운표상이 불완
전하고 약한 것으로 가정되기 때문이다(Kim, Kim et al., 2020). 그 러므로 언어치료사는 아동이 보이는 모든 오류에 대하여 전형적이 고 발달적인지 빠르게 판단할 수 있어야 하며 이를 위해서는 특정 검사 목록보다는 일반적인 발화 즉 문장이나 자발화에서 판단할 수 있는 근거도 필요할 것이다. 이 연구결과는 소수의 아동 자발화 분석을 통해 만든 틀을 단어수준에 이어서 문장수준에서 대규모 자료로 검증하고 발달적 음운 오류패턴 모형을 제안한 것에서 의 의를 찾을 수 있을 것이다.

지금까지 오류패턴의 분석 틀을 정리하는 것이 개별적으로 보이 는 오류들을 묶어서 패턴으로 해석하는 과정이었다면, 이제 말소 리장애 아동의 중재를 위한 진단 평가 과정에서는 몇 가지 오류패 턴을 좀 더 세분화할 필요가 있을 것으로 생각된다. 우선 첫 번째로 늦게까지 남는 음운 오류패턴인 유음 오류는 탄설음과 설측음으로 나누어서 분석할 필요가 있다. 두 번째로 어중종성생략이 어중종 성역행동화의 결과로 나타난 생략과 그렇지 않은 생략으로 구분될 필요가 있다. 마지막으로 문장 분석에 포함하지 않았지만 연구개음 전방화는 초성과 종성을 구분하여 분석할 수 있을 것이다. 또한 문 장수준에서 산출한 말소리 분석에 있어서 몇 가지 측면에서 아쉬 운 점이 있다. 첫째로 왜곡을 분석에서 제외하였다는 점과, 두 번째 로 상세한 동화변동을 포함하지 못한 것이다. 세 번째로 문장 과제 에서 가능한 여러가지 조건에 따른 변동, 즉 형태소의 종류, 어절내 위치, 후행 모음에 따른 오류의 차이 등을 분석하지 못했다. 그러나 아직 전형적, 혹은 비전형적 음운변동에 대한 완전한 리스트는 국 내외 어디에도 없다. 다양한 문맥과 대상자들에게 유도된 발화를 지속적으로 분석하고자 하는 시도와 정교화 과정을 통해서 보다 완성된 음운변동 분석 목록을 만들어갈 수 있을 것이다.

\section{REFERENCES}

Bernthal, J. E., Bankson, N. W., \& Flipsen, P. (2017). Articulation and phonological disorders: speech sound disorders in children (8th ed.). Boston, MA: Pearson.

Choi, M. S., \& Kim, S. J. (2013). Morphological influences on liquid acquisition in Korean children's spontaneous speech. Communication Sciences \& Disorders, 18(1), 76-85.

Dodd, B., Holm, A., Hua, Z., \& Crosbie, S. (2003). Phonological development: a normative study of British English-speaking children. Clinical Linguistic \& Phonetics, 17(8), 617-643.

Ha, J. W., \& Kim, S. J. (2020). Developmental phonological error patterns in a word-level test for children aged 2-7 years old. Communication Sciences \& 
Disorders, 25(4), 890-904.

Ha, S. H., \& Hwang, J. K. (2013). Speech measures from phonological analyses of spontaneous conversations in children between 18-47 months of age. Communication Sciences \& Disorders, 18(4), 425-434.

Hwang, S. S., \& Kim, S. J. (2015). Phonological error patterns in children from culturally and linguistically diverse backgrounds compared to children with speech sound disorders. Communication Sciences \& Disorders, 20(3), 456468.

Kim, M., Kim, S. J., \& Stoel-Gammon, C. (2017). Phonological acquisition of Korean consonants in conversational speech produced by young Korean children. Journal of Child Language, 44(4), 1010-1023.

Kim, M., Kim, S. J., \& Stoel-Gammon, C. (2020). Phonological characteristics of Korean speaking children with phonological disorders: preliminary results. Communication Disorders Quarterly, [Epub]. https://doi.org/10.1177/ 1525740120936975

Kim, M. J. (2006). The phonological error patterns of preschool children in the 'Korean test of articulation for children'. Korean Journal of Communication \& Disorders, 11(2), 17-31.

Kim, M. J., Pea, S. Y., \& Park, C. I. (2007). Assessment of phonology and articulation for children (APAC). Seoul: Human Brain Research \& Consulting.

Kim, S. J. (2014). Phonological error patterns of conversational speech produced by 2 - and 4-year-old children. Communication Sciences \& Disorders, 19(3), 361-370.

Kim, S. J., \& Lee, S. H. (2010). A comparison of Korean articulation tests for evaluation of phonological disorders. Special Education Research, 10(1), 343-359.

Kim, S. J., \& Shin, J. Y. (2015). Speech sound disorders. Seoul: Sigmapress.

Kim, S. J., \& Shin, J. Y. (2020). Speech sound disorders (2nd ed.). Seoul: Sigmaprss.

Kim, S. J., Jang, K. W., Hwang, D. H., \& Chang, M. S. (2016). Development of
Korean Speech Sound Analysis Tool (KSAT). Proceedings of the 2016 Fall Conference of the Korean Society of Speech Sciences (KSSS), 121-122.

Kim, Y. T. (1992). A study of phonological regression in 2-6 years of Korean children. Speech Science, 21, 3-24.

Kim, Y. T., Shin, M. J., Kim, S. J., \& Ha, J. W. (2020). Urimal test of articulation and phonology 2 (UTAP 2). Seoul: Hakjisa.

Kim, Y. T., Hong, G. H., Kim, K. H., Jang, H. S., \& Lee, J. Y. (2009). Receptive \& Expressive Vocabulary Test (REVT). Seoul: Seoul Community Rehabilitation Center.

Morrison J., \& Shriberg L. (1992). Articulation testing versus conversational speech sampling. Journal of Speech Hearing Research, 35(2), 259-273.

Park, G. Y., \& Kim, S. J. (2014). A comparison of phonological error patterns in the single word and spontaneous speech of children with speech sound disorders. Speech Science, 7(3), 165-173.

Pi, M., \& Ha, S. (2020). The effect of test words on phonological error patterns in typically developing children. Communication Sciences \& Disorders, 25(2), 458-469.

Preston, J. (2008). Phonological processing and speech production in preschoolers with speech sound disorders (Doctoral dissertation). Syracuse University, New York, USA.

Smit, A. B. (1993). Phonologic error distributions in the Iowa-Nebraska articulation norms project: consonant singletons. Journal of Speech, Language, and Hearing Research, 36(3), 533-547.

Wolk, L., \& Meisler, A. (1998). Phonological assessment: a systematic comparison of conversion and picture naming. Journal of Communication Disorders, 31(4), 291-314.

Woo, H. K., \& Kim, S. J. (2013). Coda sounds acquisition at word medial position in three and four-year-old children's spontaneous speech. Phonetics and Speech Sciences, 5(3), 73-81. 
Appendix 1. Task sentences

\begin{tabular}{cll}
\hline \multicolumn{3}{c}{ 목표 문장 } \\
\hline 연습 & 땡땡이와 씩씩이는 친구에요 & \multicolumn{1}{c}{ 목표 발음 } \\
1 & 땡땡이와 씩씩이는 놀러가기로 했어요 & 땡땡이와 씩씨기는 칭/친구에요 \\
2 & 자동차를 타고 동물원에 갔어요 & 땡땡이와 씩씨기는, 놀러가기로 해써요 \\
3 & 가족들과 코끼리차 맨 뒤에 앉았어요 & 가족뜰과/가 코끼리차, 맨뒤/디에 안자써요 \\
4 & 창밖으로 호랑이, 코뿔쏘가 보였어요. & 창바끄로 호랑이, 코뿔쏘가 보여써요 \\
5 & 커다란 돌고래가 춤추는 건 없어졌어요 & 커다란 돌고래가, 춤추는/능건 업써저써요 \\
6 & 키 큰 공주님 옆에서 사진 찍었어요 & 키킁/큰 공준님 여페서, 사진 찌거써요 \\
7 & 풀밭에 돗자리를 쭉 깔았어요 & 풀바테 도짜리를, 쭉 까라써요 \\
8 & 비빔밥, 수박, 팝콘을 먹었어요 & 비빔빱 수박, 팝/파코늘 머거써요 \\
9 & 햇빛이 쨍쨍 뜨거워서 땀이 났어요 & 해삐치 쨍쨍 뜨거워서, 따미 나써요 \\
10 & 쓰레기는 봉투에 담아서 돌아왔어요 & 쓰레기는 봉투에, 다마서 도라와써요 \\
11 & 참 신나는 하루였다 끝 & 참 신나는, 하루여따 끋 \\
\hline
\end{tabular}

Appendix 2. Types, opportunity, and definitions of developmental error patterns used in this study

\begin{tabular}{lllll}
\hline 대분류 & 중분류 & \multicolumn{1}{c}{ 음운 오류패턴 } & 기회 & \multicolumn{1}{c}{ 설명 } \\
\hline 전체 단어 변동 & 음절구조 변동 & 음절생략 & 104 & 축약 또는 음절 탈락 \\
& & 어말종성생략 & 14 & 어말종성의 탈락(유음 제외) \\
& & 어중종성생략 & 17 & 어중종성의 탈락(유음 제외) \\
& 동화 변동 & 어중종성역행동화 & 8 & 어중종성이 바로 뒤에 오는 어중초성의 일부 자질을 따라 변화(동화)됨 \\
음운 대치 변동 & 조음방법 & & & \\
& 유음오류 & 유음생략 & 23 & 초성 또는 종성에서 유음 탈락 \\
& 유음의 활음화 & 19 & 유음을 활음으로 대치 \\
& 유음의 비음화 & 23 & 유음을 비음으로 대치 \\
& 유음의 파열음화 & 23 & 유음을 파열음으로 대치 \\
& 마찰음오류 & 마찰음의 파열음화 & 21 & 치경마찰음을 치경파열음으로 대치 \\
& 마찰음의 파찰음화 & 21 & 치경마찰음을 경구개파찰음으로 대치 \\
& 파찰음오류 & 파찰음의 파열음화 & 18 & 경구개파찰음을 치경파열음으로 대치 \\
& 조음위치 & 연구개음의 전방화 & 26 & 연구개음의 조음위치가 앞으로 이동하여 치경음 또는 경구개음으로 산출 \\
전방화 & 발성유형 & 평음의 경음화 & 43 & 평음을 경음으로 산출 \\
경음화 & 격음의 경음화 & 19 & 격음을 경음으로 산출 \\
\hline
\end{tabular}




\section{국문초록}

\section{문장수준 검사에서 나타난 3-6세 아동의 발달적 음운 오류패턴}

김수진 ${ }^{1} \cdot$ 최영빈 ${ }^{1} \cdot$ 하지완 ${ }^{2}$

${ }^{1}$ 나사렛대학교 언어치료학과, ${ }^{2}$ 대구대학교 언어치료학과

배경 및 목적: 국내의 발달적 음운 오류패턴 분석은 단어나 자발화 수준에서 이루어졌으며 표본의 수가 적어 제한적이고 문장 수준에 서의 규준을 제공하고 있지 않다. 이에 새로 개발된 문장수준 검사를 이용하여 오류패턴의 연령별 발생률을 비교하고, 각 오류패턴에 대해 정상발달로 간주할 수 있는 연령대를 규정하고자 하였다. 방법: 전국 지역의 3 세부터 6 세까지 6 개월 간격으로 8 개 집단의 총 437 명이 참여하였다. 연령집단별 평균 오류패턴 발생률을 산출하고, 연령집단에서 $10 \%$ 이상의 아동들이 사용한 오류패턴들을 파악하였 다. 결과: 전체단어변동에서는 어중종성생략의 빈도가 가장 높았고 많은 아동들에게서 오래 지속되었다. 음운대치변동에서는 마찰음 의 파열음화, 유음생략이 가장 많은 아동에게서 빈번하게 지속적으로 나타났다. 논의 및 결론: 문장수준에서 분석한 연구결과를 단어 수준의 결과와 이전의 자발화 연구결과들과 비교하였다. 이를 토대로 여러 문맥에서 공통적으로 나타난 음운 오류패턴과 정상발달로 간주되는 연령기준을 제안하였다.

핵심어: 문장수준 검사, 음운 오류패턴, 발달적 음운 오류패턴, 우리말조음음운검사2, 말소리장애

\section{참고문헌}

김민정 (2006). 아동용 조음검사에 나타난 취학전 아동의 음운오류패턴. 언어청각장애연구, 11(2), 17-31.

김민정, 배소영, 박창일 (2007). 아동용 발음평가 (APAC). 서울: 휴브알앤씨.

김수진 (2014). 자발화에 나타나는 발달적 음운오류패턴. Communication Sciences \& Disorders, 19(3), 361-370.

김수진, 신지영 (2015). 말소리장애. 서울: 시그마프레스.

김수진, 신지영 (2020). 말소리장애 2판. 서울: 시그마프레스.

김수진, 이수향 (2010). 음운장애 평가를 위한 한국어 검사 비교. 특수교육, 10(1),343-359.

김수진, 장기완, 황득하, 장문수 (2016). 한국어말소리평가프로그램(KSAT)의 개발. 한국음성학회 가을학술대회 발표논문집, 121-122.

김영태 (1992). 서울-경기 지역 2-6세 아동의 발달기적 음운변동에 관한 연구. 말소리와 음성과학, 21,3-24.

김영태, 신문자, 김수진, 하지완 (2020). 우리말조음음운검사2(UTAP2). 서울: 학지사.

김영태, 홍경훈, 김경희, 장혜성, 이주연 (2009). 수용·표현어휘력검사(REVT). 서울: 서울장애인종합복지관.

박가연, 김수진 (2014). 말소리 장애 아동의 단어와 자발화 문맥의 음운오류패턴 비교. 말소리와 음성과학, 7(3), 165-173.

우혜경, 김수진 (2013). 자발화에 나타난 3-4세 아동의 어중종성 습득. 말소리와음성과학, 5(3), 73-81.

최민실, 김수진 (2013). 자발화에 나타난 3-4세 아동의 형태소 유형별 유음 발달 특성. Communication Sciences \& Disorders, 18(1), 76-85.

피민경, 하승희 (2020). 검사어에 따른 음운 오류패턴 비교. Communication Sciences \& Disorders, 25(2), 458-469.

하지완, 김수진 (2020). 단어 수준 검사에서 나타난 2-7세 아동의 발달적 음운 오류패턴. Communication Sciences \& Disorders, 25(4), 890-904.

하승희, 황진경 (2013). 18-47개월 아동의 자발화 분석에 기초한 말소리 측정치에 관한 연구. Communication Sciences \& Disorders, 18(4), 425-434.

황상심, 김수진 (2015). 베트남 다문화아동과 말소리장애 아동의 음운오류패턴. Communication Sciences \& Disorders, 20(3), 456-468.

\section{ORCID}

김수진(제1저자, 교수 https://orcid.org/0000-0002-9354-8504); 최영빈(교신저자, 언어재활사 https://orcid.org/0000-0001-8535-7428); 하지완(교신저자, 교수 https://orcid.org/0000-0002-1191-791X) 